\title{
Lymphostimulatory and delayed-type hypersensitivity responses to a candidate leprosy vaccine strain: Mycobacterium habana
}

\author{
N. B. SINGH, H. P. GUPTA, ANIL SRIVASTAVA, \\ HEMA KANDPAL \& U. M. L. SRIVASTAVA \\ Division of Microbiology, Central Drug Research Institute, Chattar \\ Manzil Palace, P.B. No. 173, Lucknow-226 001, India
}

Accepted for publication 7 October 1996

\begin{abstract}
Summary Lymphostimulatory and delayed-type hypersensitivity (DTH) immune responses to a candidate antileprosy vaccine Mycobacterium habana have been quantified in inbred AKR mice. $M$. habana vaccine in three physical states, live, heatkilled and $\gamma$-irradiated, was given intradermally to separate groups of mice and after 28 days these mice were given subcutaneous challenge with heat-killed M. leprae and heat-killed M. habana in the left hind footpad. Live BCG vaccine alone and in combination with $\gamma$-irradiated $M$. habana were also compared similarly. A sufficient degree of DTH response was generated in mice by $M$. habana vaccine in all physical forms against two challenge antigens (lepromin and habanin). The BCG combination with $M$. habana did not increase the DTH response indicating internal adjuvanticity endowed in $M$. habana. The active hypersensitivity of immunized mice was transferable to syngeneic mice by the transfer of sensitized cells from the donor to the recipient mice intravenously. M. leprae-infected Rhesus monkey PBMC have shown comparable stimulatory response with $M$. habana (sonicate), and $M$. leprae (sonicate) antigens. The possibility of developing $M$. habana as a candidate antileprosy vaccine is discussed.
\end{abstract}

\section{Introduction}

In mycobacterial diseases, protective immunity is mediated through bacterial kill and/or modulation of the immune response which is essentially cell mediated with two basic cell types: the T-lymphocytes and macrophages interacting through cytokines. ${ }^{1,2}$ The basis of in vivo and in vitro tests is to examine and measure the nature of the responses of these cells to the immunogens. The most commonly employed test is the delayed type of hypersensitivity response in the skin elicited by an intradermal injection of the immunogen. The in vitro tests, measuring the T-cell immunity are lymphocyte proliferation test (LPT) and the leucocyte migration inhibition test (LMIT). LMIT measures the release of lymphokines from antigenically driven lymphocytes and LPT measures DNA synthesis in actively multiplying cells due to release of lymphostimulatory factor(s). The skin DTH response assesses the individuals ability to mobilize the immunocytes to the injection site of the antigen. The DTH response evaluated in the form of a footpad enlargement (FPE) after injection of 
the antigen in animals is a way to monitor the test and to prove the indirect efficacy of antileprosy vaccines. ${ }^{3,4}$

One candidate antileprosy vaccine: $M$. habana $(M$. simiae serovar 1$)$ protects mice against infectious challenge with $M$. tuberculosis $\mathrm{H}_{37} \mathrm{Rv}, M$. leprae and $M$. ulcerans. ${ }^{5-9}$ M. habana generates a cell-mediated immune response (CMI) which recognizes $M$. tuberculosis and $M$. leprae antigens ${ }^{10,11}$ and shares several immunodominant proteins with them. ${ }^{12,13} M$. habana combines the useful traits of these mycobacteria and may suitably be developed as a vaccine against leprosy.

In this report we present the data of comparative evaluation of in vivo DTH response generated by $M$. habana and other vaccine(s) in mice and successful transfer of the active immune hypersensitivity through sensitized cells in syngeneic mice. The in vitro lymphostimulatory response of $M$. leprae sensitized monkey cells have also been studied against M. habana antigen(s).

\section{Materials and methods}

GROWTH AND PREPARATION OF IMMUNIZING ANTIGENS

Mycobacterium habana (M. simiae serovar-1, TMC 5135) was obtained from the TMC collection centre Saranac Lake, New York. The strain of BCG (Madras) was procured from the Tuberculosis Research Centre, Madras and freeze-dried preparations of armadillo derived M. leprae were obtained through Dr R. J. W. Rees of the National Institute for Medical Research Mill Hill, London. Mycobacteria other than M. leprae were maintained separately on Lowenstein-Jensen medium and their bulk growth was obtained in Sautons liquid medium. A live culture of BCG was used as vaccine, while $M$. habana vaccine was treated by $\gamma$-irradiation of the culture at $300 \mathrm{~K}$ rads from a ${ }^{60}$ cobalt source. $M$. habana was also used in live and heat-killed states for immunization. Freeze-dried M. leprae preparations was reconstituted in normal saline at the required concentration.

\section{CHALLENGE ANTIGENS}

Integral habanin was prepared from mid-log culture of $M$. habana by standard procedures as applied for the preparation of integral lepromin (WHO protocol). The Mitsuda lepromin was obtained through Professor Noordeen, Chief Medical Officer, WHO, Geneva.

\section{DOSE OF VACCINE AND ANTIGENS}

Mice were immunized i/d with $6.27 \times 10^{8}$ organisms (63.3 $\mu \mathrm{g}$ protein/animal) of M. habana in either live, heat-killed or $\gamma$-irradiated states while the dose of BCG and M. leprae were $6.0 \times 10^{5}$ and $2.0 \times 10^{7}$ bacilli per animal respectively (recommended optimal doses). The challenge dose of each antigen (habanin and lepromin) was $3 \times 10^{7}$ bacilli per footpad.

\section{THE EXPERIMENTAL ANIMALS}

Inbred AKR mice maintained in the Institute's animal house were used. The animals were kept on a pellet diet of Hindustan Lever Ltd, with water ad libitum. They were divided in groups on a similar weight basis. All vaccinations were done intradermally on the back and 28 
days postvaccination the animals were challenged with eliciting antigens in the hind feet. The footpad thickness was measured prior and after challenge with a Schnelltäster (made in Germany) and corrected footpad enlargements (FPE) were calculated according to Shepard's method. $^{4}$

\section{ADOPTIVE TRANSFER OF IMMUNITY}

Sensitized splenic cells from vaccinated mice were obtained by extirpation of the spleen and mincing and passing through a metal sieve. The method of Patel \& Lefford ${ }^{14}$ was followed with slight modifications. The viability of the cells was determined by staining with Trypan blue. $1 \times 10^{8}$ viable splenic cells obtained from actively sensitized (vaccinated) mice were given $\mathrm{i} / \mathrm{v}$ to separate groups of syngeneic mice for passive sensitization. After $24 \mathrm{~h}$ these passively sensitized mice were given a S/C challenge in the hind footpad with homo and heterologous eliciting antigens and the FPE was measured as described earlier.

\section{LYMPHOCYTE TRANSFORMATION TEST (LTT)}

Peripheral blood mononuclear cells (PBMC) were separated from heparinized blood of normal (tuberculin and lepromin negative) and $M$. leprae infected Rhesus monkeys by density gradient centrifugation (Lymphoprep-Nyegard S.Co.OSLO, Norway). These cells were washed thrice and their viability was determined by staining with Trypan blue (93\% viable). The cells were finally suspended at $2 \times 10^{6}$ cells $/ \mathrm{ml}$ in RPMI-1640 supplemented with $10 \%$ foetal calf serum (GIBCO, Grand Island, New York, USA), glutamine and antibiotics (streptomycin $100 \mu \mathrm{g} / \mathrm{ml}$, penicillin $100 \mathrm{units} / \mathrm{ml}$ and gentamycin $20 \mu \mathrm{g} / \mathrm{ml}$ ). $100 \mu \mathrm{l}$ of this suspension were dispensed in each well giving a concentration of $2 \times 10^{5}$ cells/well. The antigens used were $M$. leprae and $M$. habana sonicate (soluble fraction at 2.5, 5.0 and $10 \mu \mathrm{g} /$ well and mitogen PHA-P (Sigma Chemical Co., USA) at 0.5, 1.0 and $2.0 \mu \mathrm{g} /$ well. Control cultures received no mitogen/antigen. The cultures on day 4 were pulsed with $0.5 \mu \mathrm{Ci}$ of $\left[{ }^{3} \mathrm{H}\right]$-thymidine (specific activity of $18 \mathrm{mCi} / \mathrm{u}$ mole) obtained from Bhabha Radiation and Isotope Technology, Bombay, India. Harvesting of the cells was done on day 5 through a semiautomatic harvester (PHD cell harvester, Cambridge Technology Inc., Cambridge, Massachusetta, USA) using glass fibre filters (GF/C Whatman, England) and radioactivity was counted in a liquid Scintillation counter (LKB Finland) using a toluene based scintillation cocktail.

\section{RESULTS}

INDUCTION OF DTH RESPONSE BY DIFFERENT VACCINES

All the three preparations (live, heat killed, and $\gamma$-irradiated) of $M$. habana live, BCG, heatkilled $M$. leprae and live BCG $+\gamma$-irradiated $M$. habana were tested for generation of DTH response against homologous and heterologous antigenic challenge. The data are presented in Figure 1. Average FPE with homologous antigen-habanin are $28.33 \pm 7 \cdot 53 ; 31.43 \pm 6.90$ and $31.66 \pm 7.30$ respectively in three types of vaccinated animals. With lepromin the FPE response of these groups of animals were $26 \cdot 67 \pm 5 \cdot 15,26 \cdot 66 \pm 8 \cdot 16$ and $28 \cdot 33 \pm 7 \cdot 53$ respectively. In animals vaccinated with live BCG heat killed M. leprae and live BCG+ r-irradiated $M$. habana the responses with habanin were $23 \cdot 33 \pm 5 \cdot 16,21 \cdot 66 \pm 4.08$ and 


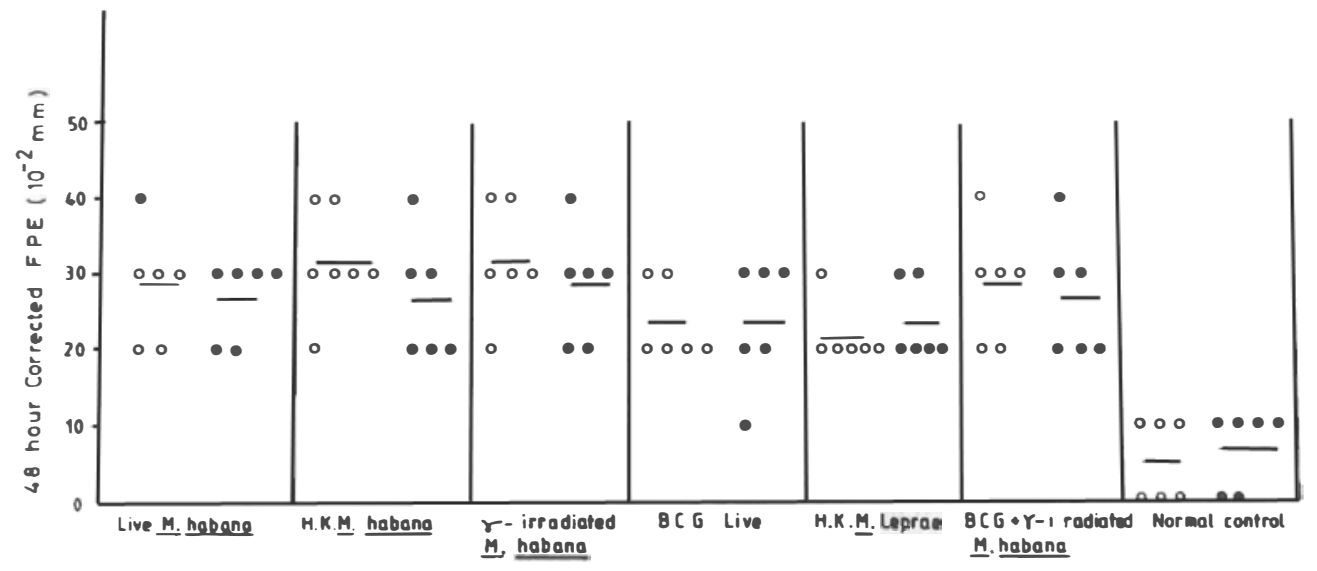

Figure 1. Forty-eight footpad enlargement in mice actively sensitized with different vaccines after challenge with habanin and lepromin. FPE in AKR mice ID route $\left(6 \cdot 27 \times 10^{8}\right.$ bacilli); $\bigcirc \rightarrow$ habanin; $\bullet \rightarrow$ lepromin.

$28.33 \pm 7 \cdot 52$ and with lepromin the responses were $23 \cdot 33 \pm 8 \cdot 16,23 \cdot 33 \pm 5 \cdot 16$, $26 \cdot 66 \pm 8 \cdot 16$ respectively. It is apparent that both the sensitins have generated sufficient degree of DTH response in vaccinated animals than unvaccinated controls. The combined vaccination of animals with $\mathrm{BCG}+M$. habana did not impart better DTH response than with either vaccine alone.

\section{ADOPTIVE TRANSFER OF IMMUNITY THROUGH SENSITIZED CELLS}

Sensitized splenic cells from mice vaccinated with $\gamma$-irradiated $M$. habana, heat-killed $M$. habana and heat-killed $M$. leprae were transferred intravenously to normal syngeneic mice. After 24 hours of passive sensitization these groups of animals were challenged with homologous and heterologous antigens. The individual animal data are presented in Figure 1. A considerably higher number of animals developed passive sensitization and had higher FPE values than the controls with both the sensitins (habanin/lepromin). Gamma irradiated $M$. habana group of passively sensitized animals had better response than other groups. The average FPE of respective groups was 23.33 $\pm 8 \cdot 16,20 \cdot 00 \pm 8.94$ and $16 \cdot 66 \pm 8 \cdot 16$ with habanin challenge and 20.00 $\pm 8 \cdot 94,18 \cdot 7 \pm 8 \cdot 99$ and $20 \cdot 00 \pm 5 \cdot 77$ with lepromin challenge.

\section{LYMPHOSTIMULATORY RESPONSE}

It is evident that optimal dose PHA-P is $1 \mu \mathrm{g} / \mathrm{ml}$ since this dose has generated maximum response in normal as well as $M$. leprae sensitized monkeys. The other two doses of PHA-P (one less, other higher) have also responded well but less than the optimal dose of $1 \mu \mathrm{g} / \mathrm{ml}$. The lymphostimulatory responses with leprosin and habanin have also indicated that $0.5 \mu \mathrm{g} /$ $\mathrm{ml}$ dose of both the antigens are optimum. Habanin has generated the LP response closer to PHA-P where as homologous response with leprosin and habanin have also indicated that $0.5 \mu \mathrm{g} / \mathrm{ml}$ dose of both the antigens are optimum. Habanin has generated the LP response closer to PHA-P where as homologous response with leprosin is of a lower order. 


\section{Discussion}

The delayed-type hypersensitivity response is one of the several parameters used to test the indirect efficacy of cell-mediated immunity (CMI) to candidate vaccines. The test is conducted by inoculating the vaccine strain intradermally in mice and challenging the vaccinated mice S/C in the footpad after 3-4 weeks with heat-killed M. leprae. The footpad enlargement (FPE) is measured after 24 and $48 \mathrm{hr}$ of challenge. Sensitized PBMC either by production of disease and/or by artificial in vitro sensitization when allowed to react with the specific antigen(s) secrete lymphocyte stimulatory factor(s) which stimulate the sensitized cells to proliferate profusely. This cell division is measured in terms of DNA synthesis which increases many fold. This test is specific in recognizing the antigenic relatedness/similarity between species/strains.

M. habana (M. simiae) an atypical mycobacterium, has afforded protection against $M$. leprae and $M$. tuberculosis infectious challenges: in mice. ${ }^{5-8}$ It generates strong cellmediated immune responses, possesses several common and specific immunodominant protein epitopes with $M$. leprae, and $M$. tuberculosis and BCG. ${ }^{10-13}$

This study was undertaken to elucidate, if $M$. habana stimulates DTH responses in mice which could be recognized by $M$. leprae antigens and whether $M$. habana antigen(s) could produce lymphostimulatory response in $\mathrm{PBMC}(\mathrm{s})$ obtained from $M$. le prae sensitized Rhesus monkeys.

M. habana vaccine in all the physical states (i.e. live, heat-killed and $\gamma$-irradiated) was able to generate DTH response against the homologous antigen habanin and the heterologous antigen lepromin. The DTH responses stimulated by heat-killed and $\gamma$-irradiated $M$. habana were apparently better than that stimulated by live vaccine although there were no statistically significant differences. This finding correlates well with a similar findings with heat-killed M. leprae by Shepard et al. ${ }^{16}$ This may possibly be due to exposure of other antigens normally at some inaccessible regions after gamma irradiation or heat treatment. The DTH response stimulated by live BCG was inferior to those stimulated by other vaccines, although a heat-killed preparation of BCG was not included. It has been proved beyond doubt by several investigators that killed BCG does not sensitize mice. ${ }^{16}$ The combined vaccination with live BCG and $\gamma$-irradiated $M$. habana did not increase sensitization more than either vaccines alone, which may possibly be due to internal adjuvanticity in $M$. habana. In animals, heat-killed $M$. leprae in combination with BCG does not enhance sensitization, ${ }^{17,18}$ although in contrast to this, BCG in combination with heat-killed $M$. leprae in man provides an adjuvant effect. ${ }^{19,20}$ This property of $M$. habana and $M$. leprae seems to be similar in animals. Data for humans in respect of $M$. habana vaccine are not available at present, which is in progress. Heat-killed $M$. leprae was a poor sensitizer of mice than $M$. habana in our hands, whether tested against habanin or lepromin.

Like $M$. leprae ( $\gamma$-irradiated), BCG and other candidate leprosy vaccines, $M$. habana also produces adoptive immunity which is transferable to syngeneic mice with actively sensitized cells.

M. habana antigen(s) have also stimulated strong lymphostimulatory responses, comparable to those stimulated by $M$. leprae antigen(s) in $\mathrm{PBMC}(\mathrm{s})$ from $M$. leprae sensitized Rhesus monkeys. This indicates sharing of common epitopes between these two mycobacteria.

Since $M$. habana possesses several immunogenic, it could be developed as a vaccine for the prophylaxis/immunotherapy of leprosy. 


\section{Acknowledgment}

The authors are grateful to Dr V. P. Kamboj, Director and Dr G. P. Dutta, Head, Division of Microbiology, Central Drug Research Institute, Lucknow for their keen interest in the work. The technical help of Sri Horilal, and Sunil Chakraborty was appreciable and is duly acknowledged. The authors are thankful to the Biometery \& Statistics Unit for analysis of the data.

\section{References}

1 Nath I. Immunological aspects of human leprosy. Lepr Ind, 1983; 55: 752-762.

2 Bloom BR. Rationales for vaccine against leprosy. Int J Lepr, 1983; 51: 505-509.

3 Shepard CC, Van Landingham R, Walker LL. Searches among mycobacterial cultures for antileprosy vaccines. Infect Immunity, 1980; 29: 1034-1039.

4 Shepard CC, Minagawa F, Van Landingham R, Walker LL. Foot pad enlargement as a measure of induced immunity to Mycobacterium leprae. Int J Lepr, 1980; 48: 371-381.

${ }^{5}$ Gupta HP, Singh NB, Mathur IS, Gupta SK. A new immunogenic strain Mycobacterium habana in experimental tuberculosis of mice. Ind J Exp Biol, 1979; 17: 1190-1193.

6 Singh NB, Srivastava A, Gupta HP, Sreevatsa, Desikan KV. Immunological potential of cutivable mycobacterial strain M. habana against leprosy bacillus in mouse foot pad. Ind J Lepr, 1985; 57: 278-281.

${ }^{7}$ Gupta HP, Singh NB, Ashok Kumar. Containment of Mycobacterium leprae multiplication in foot pad of $M$. habana vaccinated animals. Biological Memoirs, 1987; 13: 174-178.

${ }^{8}$ Singh NB, Lowe ACRE, Rees RJW, Colston MJ. Vaccination of mice against M. leprae infection. Infect Immunity, 1989; 57: 653-655.

9 Singh NB, Mathur IS, Gupta HP, Srivastava A. A novel immunogenic strain Mycobacterium habana against $M$. ulcerans (Buruli ulcer) infection in mice. Curr Sci, 1981; 50: 994-996.

10 Singh NB, Gupta HP, Mathur IS, Ashok Kumar, Chakraborty SK. Leukocyte migration inhibition response of Mycobacterium habana with sensitized animals and leprotic human cells. Ind J Lepr, 1985; 57: 273-277.

11 Singh NB, Srivastava A, Gupta HP, Ashok Kumar, Chaturvedi VK. Relative cross reactivity of habanin, lepromin and tuberculin in guineapigs sensitized with homologous and heterologous mycobacteria. Ind J Lepr, 60: 407-412.

12 Singh NB, Sinha S. Comparison of antigenic profile of a candidate vaccine strain M. habana with other mycobacteria by poly-acrylamide gel. Curr Sci, 1985, 54: 568-569.

13 Lamb FI, Singh NB, Colston MJ. The specific 18 kilo dalton antigen of $M$. leprae is present in $M$. habana and functions as heat shock protein. J Immunol, 1990; 144: 1922-1925.

14 Patel PJ, Lefford MJ. Specific and non-specific resistance in mice immunized with irradiated M. leprae. Infect Immunity, 1978; 20: 692-697.

15 Jeevan A, Bapat CV. Induction of delayed type hypersensitivity by ICRC antileprosy vaccine and the adoptive transfer of cell mediated immunity in mice. Ind J Lepr, 1984; 56: 754.

16 Shepard CC, Walker LL, Van Landingham R. Heat stability of Mycobacterium leprae immunogenicity. Infect Immunity, 1978; 22: 87-93.

17 Mehra V, Bloom BR. Induction of cell-mediated immunity to Mycobacterium leprae in guineapigs. Infect Immunity, 1979; 23: 787-794.

18 Shepard CC, Van Landingham R, Walker LL. Immunity to Mycobacterium leprae infections in mice stimulated by $M$. leprae, BCG and graft versus host reactions. Infect Immunity, 1976; 14: 919-928.

19 Convit J, Aranzazu N, Pinardi M, Ulrich M. Immunological changes observed in intermediate and leprosy patients and Mitsuda negative contacts after the inoculation of a mixture of M. leprae and BCG. Clin Exp Immun, 1979; 36: 214-220.

${ }^{20}$ Convit J, Aranzazu N, Ulrich M, Pinardi ME, Reyes O, Alvarado J. Immunotherapy with a mixture of M. leprae and BCG in different forms of leprosy and in Mitsuda negative contacts. Int J Lepr, 1982; 50: 415-424. 